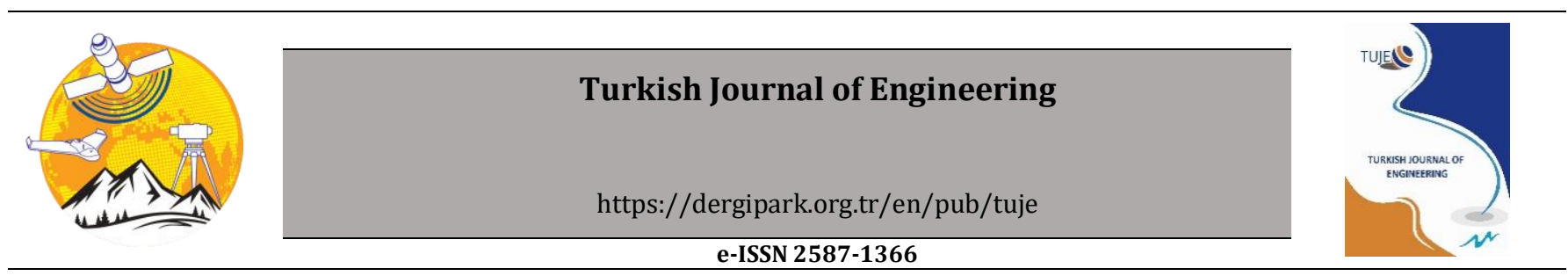

\title{
Determination to the period of a school building before and after its retrofitting using ambient vibration records
}

\author{
Selcuk Kacin ${ }^{1}$, Halil Cagri Yilmaz ${ }^{1 * \mathbb{C}}$, Cemil Vedat Caglar ${ }^{1}$ \\ ${ }^{1}$ Iskenderun Technical University, Faculty of Engineering and Natural Sciences, Department of Civil Engineering, Hatay, Turkey
}

\author{
Keywords \\ SHMSs \\ Retrofitting \\ Dynamic Analysis \\ Ambient Vibration Records \\ OMA
}

\begin{abstract}
Determining the dynamic parameters of the structures allows us to obtain a substantial amount of information about the state of the building. Recently, the determination of these parameters were performed through Structural Health Monitoring Systems (SHMSs), which are non-destructive methods. In scope of this study, the period values prior to and following the retrofitting of a school building, which are among the dynamic parameters, were examined. The Operational Modal Analysis (OMA) method, which is based on the principle of measuring the responses of ambient effects in the structure in the experimental study, has been utilized. For this purpose, response records taken from the building under the effect of ambient vibration were used. Before and after retrofitting, the records of the building under the effect of ambient vibration were taken from the same locations. 3 sensors were used to record ambient vibrations. The data from these sensors were transferred to a computer by using a data logger. In order to measure and evaluate the responses Enhanced Frequency Domain Decomposition Method (EFDDM) in the frequency domain and Stochastic Subspace Identification Method (SSIM) in the time domain were used. Following the analysis, a comparison of how the period values had changed was conducted.
\end{abstract}

\section{INTRODUCTION}

The structures show many different characteristics under dynamic loads. Besides the uncertainties under dynamic loads, the uncertainties in the parameters affecting the dynamic behavior make it difficult to determine the dynamic behavior of the structures realistically. The identification of the dynamic characteristics of structures is an increasingly used method, especially in existing buildings. These characteristics are of particular importance for historical structures for which we do not have sufficient or precise information and complex and huge systems such as civil engineering structures (Safak 2007). Experimental data can be used to solve the problem of determining dynamic parameters. Experimental Modal Analysis (EMA) is a method adopted to determine dynamic parameters (Maia and Silva 1997; Ewins 1995; Mirtarehi and Salehi 2018). Dynamic parameters usually consist of frequency, damping ratio, mode shape, modal participation factor. In the Experimental Modal Analysis, structures are excited by one or several measured forces, the responses of the structures are recorded. Modal models for the structures are identified from the input-output data. Finally, the modal parameters of the structures are extracted from the identified modal models. However, most civil engineering structures (bridges, buildings, etc.) are under ambient loads such as wind, traffic, and earthquakes. And since these loads are immeasurable, the input force cannot be fully defined. In addition, it is both costly and difficult to vibrate these huge structures with equipment. For these reasons, methods and algorithms that perform modal analysis of structures using only output data have been developed. This method, which is included in the literature as Operational Modal Analysis (OMA) or ambient vibration analysis, is a method based on output responses only (Van Overschee and De Moor 1993 ; Brincker et al. 2000 ; Bayraktar et al. 2009; Zhu et. al 2018; Singh and Grip 2019). It has become a frequently used method in recent years due to the fact that the method uses only output data as well as for, its applicability and low cost. 
High sensitivity accelerometers are required to measure vibrations in buildings. With the technology developing from the past to the present, the use of accelerometers that can measure with high sensitivity has gained great speed in vibration analysis. In this way, the predominant period and other dynamic parameters of the building can be determined in a short time with the sensors placed in buildings under ambient vibrations. Many methods with the same mathemetical bases yet different algorithms are used in the analysis of the response records. The main difference between the methods is that the variable is in the time domain or frequency domain. Methods in the frequency domain are based on the analysis of the signal measured at each point and the correlation between the signals (Bru et al. 2015). Methods in the time domain are based on the time history of the signal at each point or fitting a model with correlation functions. Within the scope of the experimental study, in the assessment of ambient vibration records taken before and after reinforcement, two commonly favored approaches were used. These are the Enhanced Frequency Domain Decomposition (EFDD) method, one of the frequency-domain methods, and the Stochastic Subspace Identification (SSI) method, one of the time-domain methods (Gunes and Anil 2017; Diaferio et al. 2007; Shokravi et al. 2020a; Shokravi et al. 2020b).

\section{GENERAL DESCRIPTION OF THE BUILDING INVESTIGATED}

In the experimental study, the ambient vibration records were taken from the B block of the school building, which is a reinforced concrete structure and consists of two blocks (Fig. 1).

The school building consists of 4 floors, each floor with a height of $2.95 \mathrm{~m}$. The building generally consists of $15 \mathrm{~cm}$ thick slab, $25 \times 60 \mathrm{~cm}$ cross-section beams and $25 \times 60 \mathrm{~cm}$ or $35 \times 60 \mathrm{~cm}$ cross-section columns. The compressive strength of the concrete used in the construction of the school building was determined to be 15.41 Mpa average.

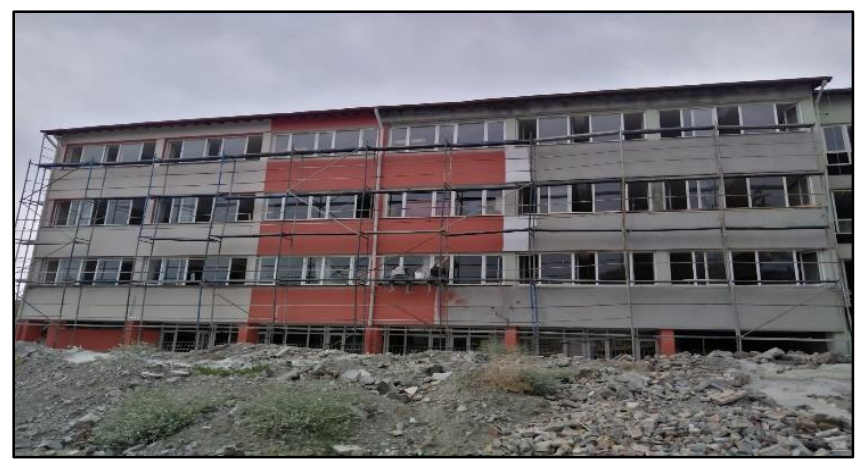

Figure 1. View of the school building

The current situation of the building has been analyzed as a result of extensive studies. According to the analysis results, it was decided to add shear walls to the building in two directions. The school building plan before and after retrofitting is shown in figure 2(a) and 2(b).

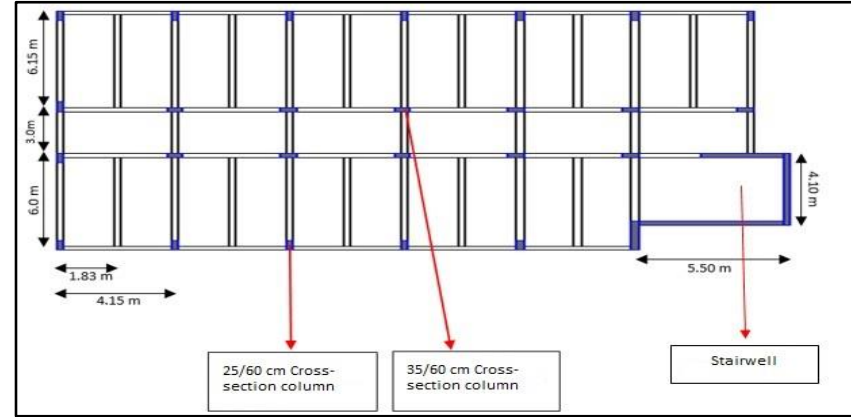

(a)

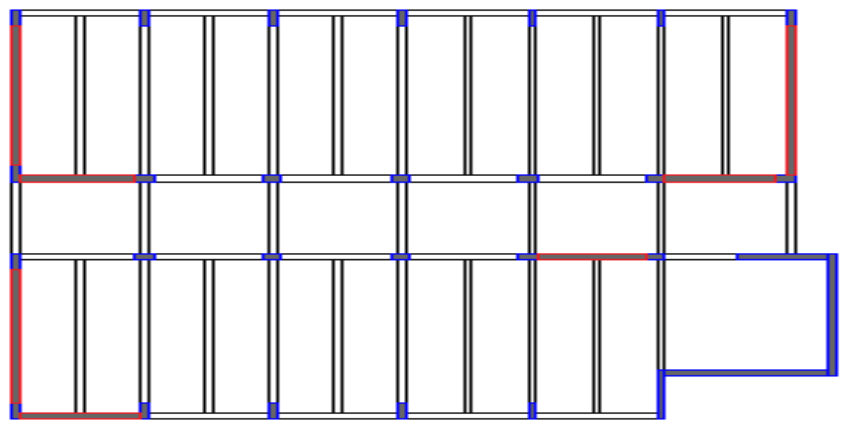

(b)

Figure 2. View of the school building B block plan; (a) before retrofitting (b) after retrofitting

\section{METHOD}

\subsection{Ambient vibration records from school building}

In order to determine the dynamic properties of the structures, several different methods are used to obtain the vibration response records of the structures. One of these methods is to wait for an earthquake by placing recording devices and to record the behavior of the building under the effect of earthquakes. In another method, the harmonic external load is given to the structure with a vibration generating device and the reaction of the structure against this load is recorded. In this study, the structure responses were recorded under the influence of ambient vibration, which is another method. There are vibrations that occur and spread due to natural reasons or human activities, which we can also call ambient vibrations in the earth, such as small earthquakes, traffic loads, big engines, etc. These vibrations, which occur due to aforementioned reasons and have amplitudes that are too small to be felt by humans, can be measured with sensitive recording devices.

In this study, structural response values were recorded under the influence of ambient vibration before retrofitting. For this purpose, accelerometer sensors were placed on the building.

In order to measure the response records of the building under the effect of ambient vibration, accelerometers - property of the Department of Civil Engineering of Iskenderun Technical University - with the feature to make 3 dimensional recordings were used. Response records were obtained using the TESTBOX2010 series, which is a 16-channel data acquisition unit (Fig. 3). Approximately 30-minute long response records were taken from the school building. The sampling frequency of the response records of the 
building under the effect of ambient vibrations is in the range of $0-100 \mathrm{~Hz}$ and the time interval is taken as 0.01 second.

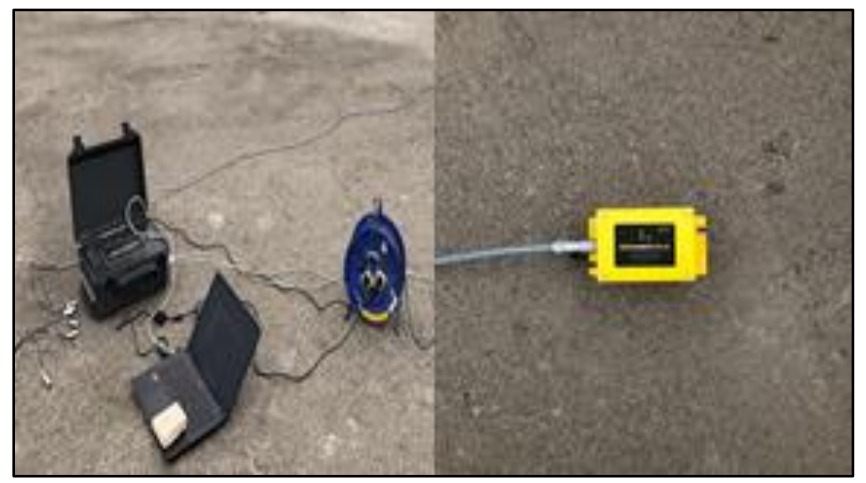

Figure 3. View of data acquisition unit and sensor

With the addition of shear walls to the building during the school building retrofitting, the building's horizontal load capacity was significantly increased (Fig 4.). During the shear wall application, the infill wall materials between the columns and beams were demolished and cleaned. In the reinforcement application, the joints of the floors with the beams were drilled and the longitudinal reinforcements of the additional shear walls were continuously transferred from floor to floor, and the rods were placed with a two-component epoxycontaining chemical anchoring system in the holes where the drilling process was applied to the existing columns and beams. Ambient vibration records were taken from the same points with sensors after retrofitting (Celebi and Liu, 1998 ; Kacin et al. 2011 ; Motosaka et al. 2004 ; Takada et al. 2004).

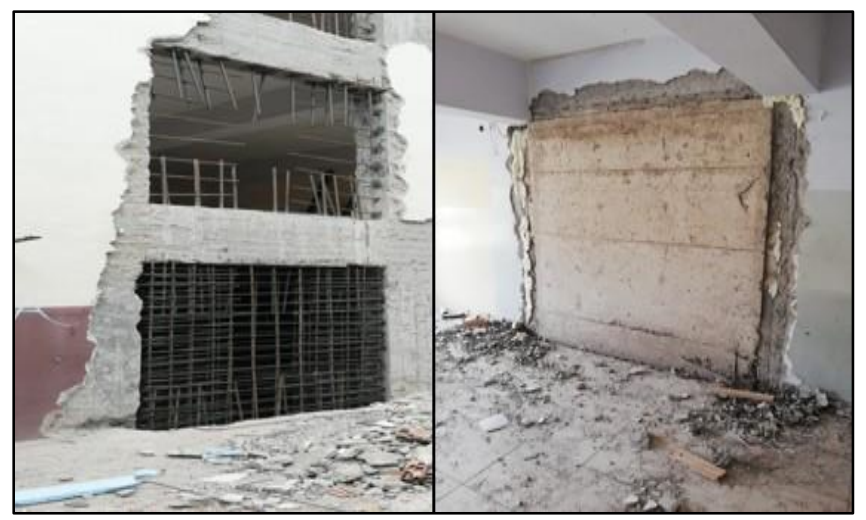

Figure 4. Adding shear walls

\subsection{Numerical values}

\subsubsection{Calculation of the period with ambient vibration records}

ARTeMIS Modal software (SVS, 2010) was used to analyze the vibration data obtained from the data collection system in the experiment. Firstly, a simple model to represent the building was created in the software. Then the vibration data (acceleration-time) obtained was transferred to the program and placed on the relevant floors of the model created as a representation (Fig. 5).

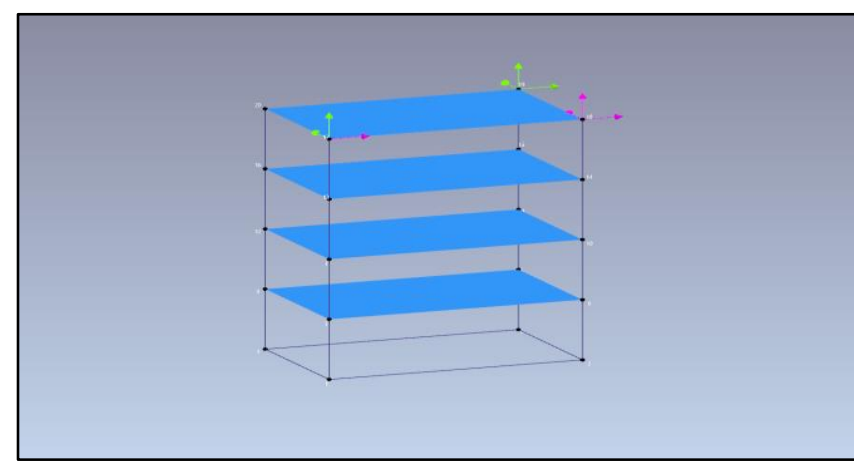

Figure 5. Model of school building and placed sensors

Amplitude-frequency values were obtained by transforming the vibration data from acceleration-time domain to acceleration-frequency domain by Fast Fourier Transformation (FFT) method. After the FFT values were processed, these values were analyzed with both SSI and EFDD aproaches (Fig. 6a and 6b). The predominant period of the school building was calculated after the analysis. The same analyses were done after retrofitting.

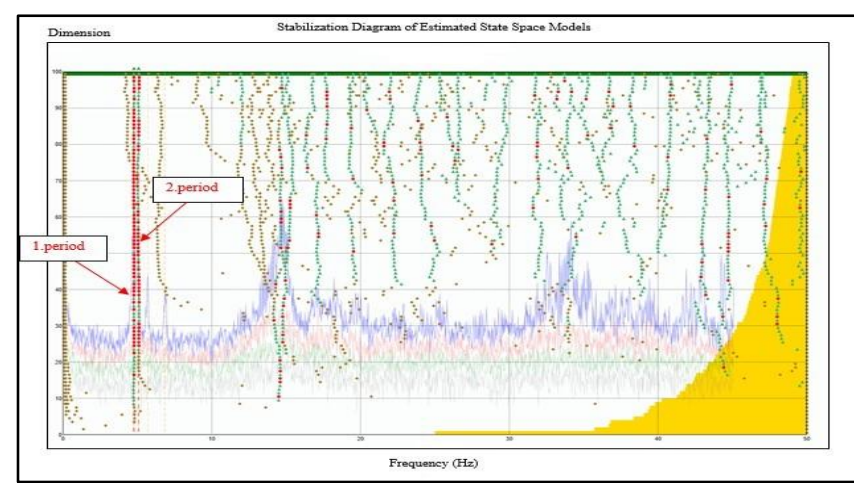

(a)

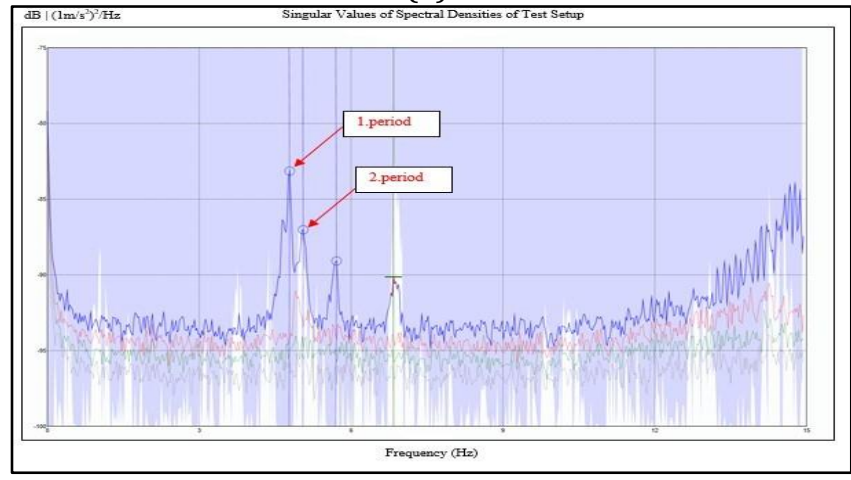

(b)

Figure 6. Analysis results; (a) SSI analysis (b) EFDD analysis

\subsubsection{Calculation of the period with structural analsis software}

After the results of the experimental study, the building was modeled with a structural analysis program (CSI, SAP2000 2015) for comparison. The concrete compressive strength that makes up the school building was defined as $15.41 \mathrm{Mpa}$. In retrofitting, C30 (30 $\mathrm{N} / \mathrm{mm} 2$ ) grade concrete properties were defined for shear wall. Infill walls were defined based on the cross bar assumption. The school building modeled with the structural analysis program was shown in figures $7 \mathrm{a}$ and 
7b. In addition, the school building modelled without walls.

Assumptions and formulas related to the modeling of diagonal bars are given below, as defined in Turkish Building Earthquake Code 2018 (TBE) and FEMA 306 (TBEC 2018, FEMA 306 1999). Eqs. (1)-(2) are given for the width of the infill wall by taking the current thickness of the infill wall. After modelling the predominant period of the school building were determined for before and after retrofitting. The school building model with walls was choosen to comparison due to its analysis results.

$$
\begin{aligned}
& a_{\text {wall }}=0.175\left(\lambda_{\text {wall }} \times \mathrm{h}_{\mathrm{k}}\right)^{-0.4} \times \mathrm{r}_{\text {wall }} \\
& \lambda_{\text {wall }}=\left[\left(\mathrm{E}_{\text {wall }} * \mathrm{t}_{\text {wall }} * \operatorname{Sin} 2 \theta\right) /\left(4 * \mathrm{E}_{\mathrm{c}}{ }^{*} \mathrm{I}_{\mathrm{k}} * \mathrm{~h}_{\text {wall }}\right)^{0.25}\right.
\end{aligned}
$$

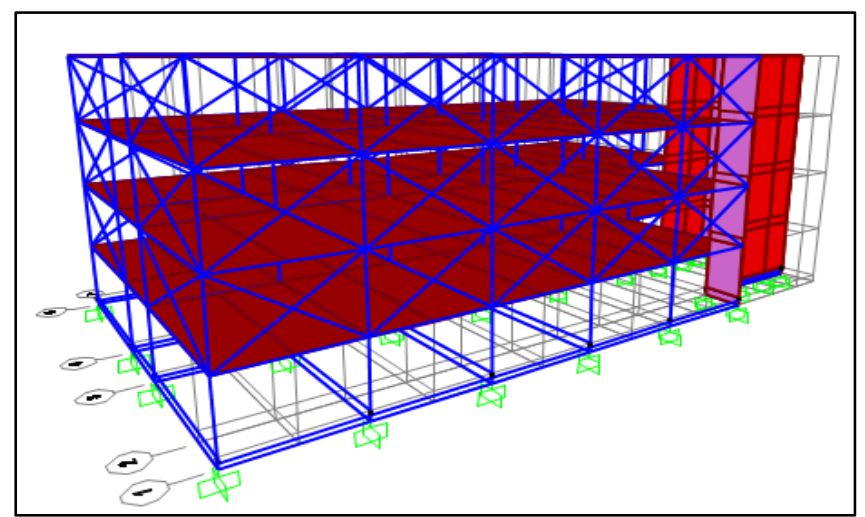

(a)

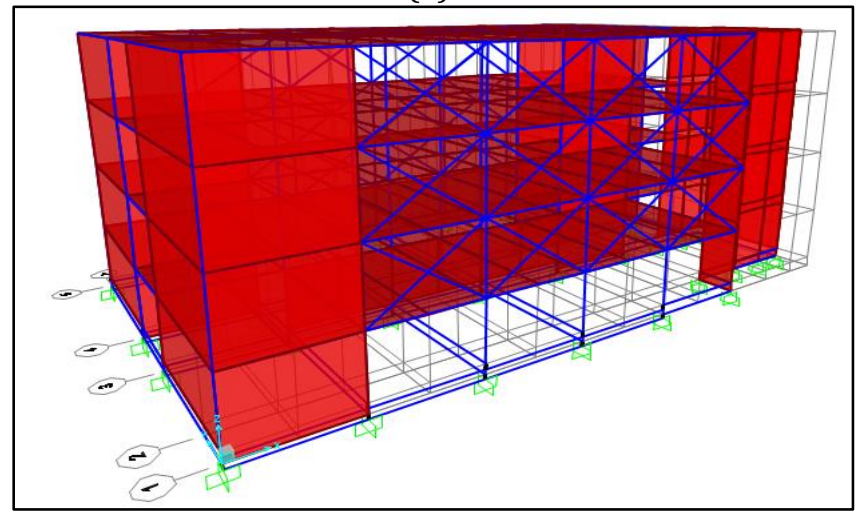

(b)

Figure 7. General view of school building; (a) before retrofitting (b) after retrofitting

After the analyses, calculated periods were shown as a comparison for both experimental study and structural analysis program (Table 1 ).

Table 1. Periods before and after retrofitting

\begin{tabular}{ccccc}
\hline & Periods & $\begin{array}{c}\text { Before } \\
\text { Retrofit- } \\
\text { ting(sn) }\end{array}$ & $\begin{array}{c}\text { After } \\
\text { Retrofit- } \\
\text { ting(sn) }\end{array}$ & $\begin{array}{c}\text { Differ- } \\
\text { ence } \\
(\%)\end{array}$ \\
\hline $\begin{array}{c}\text { Experimental } \\
\text { results }\end{array}$ & 1. & 0.21 & 0.18 & $\% 16.3$ \\
\hline $\begin{array}{c}\text { Sap2000 } \\
\text { results with }\end{array}$ & 1. & 0.20 & 0.15 & $\% 23.1$ \\
$\quad 2$. & 0.29 & 0.16 & $\% 44.8$ \\
walls & & & 0.13 & $\% 38.1$ \\
\hline $\begin{array}{c}\text { Sap2000 } \\
\text { results }\end{array}$ & 1. & 0.42 & 0.16 & $\% 61.9$ \\
without walls & 2. & 0.27 & 0.15 & $\% 44.4$ \\
\hline
\end{tabular}

\section{CONCLUSION}

In this study, how to change the periods of reinforced concrete school buildings with retrofitting was studied. For this purpose, measurements were made under ambient vibrations in order to determine before and after retrofitting period values. The school building, which does not provide sufficient performance level, has been strengthened with shear walls. Ambient vibration records were taken by placing high-sensitivity sensors on the top floor of the school building. The determination of the period values with the ambient vibration records obtained was made with two different approaches of the Operational Modal Analysis method. As a result of the analysis, the periods of the school building were obtained as $0.21,0.20$, respectively, as a result of the experimental study before retrofitting. In the experimental study carried out after the strenghtening, the periods of the school building were obtained as 0.18 and 0.15 , respectively. The period values obtained show the first and second periods of the school building, respectively. After the retrofitting, the first period and second period are decreased \% 16.3 and \% 23.1, respectively. As a result of the analysis of the school building modeled with walls with the structural analysis program before retrofitting, the period values were found 0.29 and 0.21 , respectively. The period values after retrofitting were found 0.16 and 0.13 , respectively. As a result of structure analysis program, after the retrofitting, the first period and second period are decreased \% 44.8 .3 and \% 38.1, respectively. The shear walls added to the school building with the retrofitting provided an increase in the first two natural frequencies of the building, in other words, a decrease in the period of the building. This is to be expected thanks to the increase in the stiffness of the school building with the addition of shear walls.

\section{Author contributions}

Selcuk Kacin: Conceptualization, Methodology, Supervision, final revision. Halil Cagri Yilmaz: Data curation, Writing-Original draft preparation, Software, Validation. Cemil Vedat Caglar: Visualization, Investigation. All authors have read and agreed to the published version of the manuscript.

\section{Conflicts of interest}

The authors declare no conflicts of interest.

\section{REFERENCES}

Bayraktar A, Turker T, Sevim B, Altunisik A C \& Yildirim F (2009) Modal Parameter Identification of Hagia Sophia Bell-tower via Ambient Vibration Test. Journal of Nondestructive Evaluation.

Brincker R, Zhang L \& Andersen P (2000). Modal Identification from Ambient Responses using Frequency Domain Decomposition. In Proceedings of the 18th IMAC. San Antonio, Texas. 
Bru D, Ivorra S, Baeza F J, Reynau R \& Foti D (2015). OMA dynamic identification of a masonry chimney with severe cracking condition. 6th International Operational Modal Analysis Conference (IOMAC15), Gijon, Spain,

Celebi M \& Liu H P (1998).Before and after retrofit response of a building during ambient and strong motions. Journal of Wind Engineering and Industrial Aerodynamics, 77\&78: 259-268.

Diaferio M, Foti D \& Sepe V (2007). Dynamic Identification of the Tower of the Provincial Administration Building, Bari, Italy. Proc. of the Eleventh International Conference on Civil, Structural and Environmental Engineering Computing, Malta,p. 21. DOI:10.4203/ccp.86.2

Ewins D J (1995) Modal Testing: Theory and Practice. Wiley, NewYork. ISBN : 978-0-863-80218-8

Federal Emergency Management Agency, FEMA, 306 (1999) "Manual, B.P. Evaluation of earthquake damaged concrete and masonary wall buldings." .

Gunes S \& Anil O (2017). Operasyonel Modal Analiz Tekniği ile Yığma Yapların Dinamik Davranışının Belirlenmesi . 4.UDMSK, 4. Uluslararası Deprem Mühendisliği ve Sismoloji Konferansı.

Kacin S, Bikce M, Genes M C, Doganay Ela \& Unlusoy U (2011). Güçlendirme uygulaması yapılan bir binanın güçlendirme öncesi ve sonrasında titreşim ölçümleri ile bazı dinamik parametrelerinin hesaplanması. Yedinci Ulusal Deprem Mühendisliği Konferansı İstanbul: İstanbul Teknik Üniversitesi.

Maia J M \& Silva J M (1997). Theoretical and Experimental Modal Analysis. Taunton, Somerset, England: New York: Research Studies Pre.

Mirtaheri M \& Salehi F (2018). Ambient vibration testing of existing buildings: experimental, numerical and code provisions. Advances in Mechanical Engineering, 10(4), 1687814018772718.https://doi.org/10.1177/1687 814018772718

Motosaka M, Sato T \& Yamamoto Y (2004). The amplitude dependent dynamic characteristics of an existing building before and after seismic retrofit. Proc. 13th World Conf. on Earthquake Engineering, Paper No: 1023, August 1-6, Vancouver, Canada.
Safak E (2007). Yapı Titreşimlerinin İzlenmesi: Nedir, Neden Yapılır, Nasıl Yapılır, ve Ne Elde Edilir? Altıncı Ulusal Deprem Mühendisliği Konferansı (ss. 285293). İstanbul: İstanbul Teknik Üniversitesi

Shokravi H, Shokravi H, Bakhary N, Rahimian Koloor S S, \& Petrů M (2020). Health monitoring of civil infrastructures by subspace system identification method: an overview. Applied Sciences, 10(8), 2786. https://doi.org/10.3390/app10082786

Shokravi H, Shokravi H, Bakhary N, Heidarrezaei M, Rahimian Koloor S S \& Petrů M (2020). Application of the Subspace-Based Methods in Health Monitoring of Civil Structures: A Systematic Review and MetaAnalysis. Applied

Sciences, 10(10),3607.https://doi.org/10.3390/app 10103607

Singh H \& Grip N (2019). Recent trends in operation modal analysis techniques and its application on a steel truss bridge.

Structural Vibration Solutions (SVS). 2010. ARTeMIS Extractor 2010. Copenhagen, Denmark: Aalborg University/SVS A/S. Available at: http://www.svibs.com

SAP2000. Linear and nonlinear static and dynamic analysis and design of three-dimensional structures. Berkeley (CA), Computers and Struc-tures Inc. (CSI). 2015.

Turkish Building Earthquake Code (TBEC-2018), Afet ve Acil Durum Yönetimi Başkanlığı, Resmi Gazete, Sayı: 30364 (Mükerrer), 18 Mart 2018

Takada T, Iwasaki R, An D D, Itoi T \& Nishikawa N (2004). Dynamic Behavior Change of Building Before and After Seismically Retrofitting. Proc. 13th World Conf. on Earthquake Engineering, Paper No: 1237, August 1-6, Vancouver, Canada.

Van Overschee P \& De Moor B (1993). Subspace algorithms for the stochastic identification problem. Automatica, 29(3), 649-660.

Zhu Y C, Xie Y L, Au S K (2018). Operational modal analysis of an eight-storey building with asynchronous data incorporating multiple setup, Engineering Structures, 165, 50-62 